УДК 378.014.53:005.336.4

DOI:

Наталія Долінська, кандидат педагогічних наук, доиент кафедри іноземних мов факультету міжнародних відносин Львівського національного університету імені Івана Франка

\title{
ПРОФЕСІЙНИЙ КАПТТАЛ У ВИЩІЙ ШКОЛІ: ПОНЯТТЯ І РОЛЬ
}

У статті проаналізовано наповнення та зміст категорії “професійний капітал” у вищій школі та запропоновано трактування иього поняття як педагогічної категорії. Виокремлено та охарактеризовано складові професійного капіталу в галузі вищої освіти, до яких належать нематеріальні ресурси закладів вищої освіти охоплені інтелектуальним, соціальним та рішеннсвим капіталом. Розглянуто інтелектуальний капітал як категорію, яка охоплює людський та організаційний (структурний капітал). Наголошено на значущості загалом професійного капіталу та його складових як головних передумов забезпечення високоі якості вищої освіти.

Ключові слова: професійний капітал; людський капітал; сочіальний капітал; ріменнєвий капітал; інтелектуальний капітал; капітал; співробітництво; вища освіта; заклад вищої освіти.

Puc. 1. Лim. 9.

Nataliya Dolinska, Ph.D.(Pedagogy), Associate Professor of the Foreign Languages Department, Faculty of International Relations, Ivan Franko National University of Lviv

\section{PROFESSIONAL CAPITAL IN HIGHER EDUCATION: CONCEPT AND ROLE}

The issue of efficient use of non-material resources both in business and education is currently generating increasing scientific interest across the globe. In this regard the article deals with the concept of professional capital and its components as the major prerequisites of ensuring high quality and efficiency of higher education. Professional capital of higher education is viewed as synthesis of intellectual, social and decisional capital of institutions of higher education which in their turn are realized through interpersonal communication, cooperation and networking, knowledge and experience of university employees, faculty, students and other higher education stakeholders, their relationships, achievements and decisions which altogether ensure the high quality and efficiency of higher education. Major components of professional capital, i.e. intellectual (including human and organizational capital), social, and decisional capital are characterized and detailed with respect to higher education. Human capital of higher education, an integral element of its intellectual capital, is analyzed and viewed at the following levels: personal (the level of an individual), microeconomic (the level of an institution), and macroeconomic (the level of higher education of a nation or the world). Social capital is primarily based on cooperation which is realized through the listed major activities within academia. Decisional capital involves making decisions in complex situations on innumerable occasions with a variety of problems and cases. Finally, the interpretation of professional capital of higher education is provided and its significance in ensuring high quality and efficiency of education is stressed as well as prospects for future research are outlined.

Keywords: professional capital; human capital; social capital; decisional capital; intellectual capital; capital; cooperation; higher education; institution of higher education.

П остановка проблеми. У сучасних умовах ринкової економіки, яка диктує власні правила виживання та процвітання не лише для суб'єктів господарської діяльності, а й для закладів вищої освіти, необхідно усвідомити важливість їх адміністрування за зразком менеджменту підприємств, проаналізувати ефективність використання нематеріальних ресурсів, які забезпечують якість вищої освіти. На відміну від українських університетів, закономірно, політика й адміністрування закладів вищої освіти США, які виникли та сформувалися в умовах ринку, мають високу ефективність 3 економічної точки зору i залишаються найбажанішими університетами світу серед абітурієнтів, дослідників та викладачів. Усе ж, під впливом сучасних соціально-економічних та організаційно-технологічних чинників, питання постійного підвищення якості освіти $\epsilon$ центральною темою освітнього дебату в США. Серед іншого, однією з найвпливовіших сучасних тенденцій є виокремлення поняття професійного капіталу й аналіз проблематики його наповнення в умовах вищої школи. Грунтуючись на функціональному підході до визначення поняття професійного капіталу у вищій школі, у цій статті ми пропонуємо спробу авторського трактування цього поняття.

Аналіз останніх досліджень і публікацій. Значну увагу визначенню та дослідженню сутності категорії “професійний капітал” у вищій школі присвячено у дослідженнях американських 
науковців Е. Гаргрівза, М. Фуллана та Дж. Прудена. В українських дослідженнях поняття професійного капіталу не розглядалося, однак у науковій економічній літературі досить глибоко проаналізовано дотичні категорії: людський капітал, соціальний капітал, інтелектуальний капітал. Розробці проблем, пов'язаних 3 інтелектуальним капіталом, присвячено праці В. Базилевича, В. Врублевського, О. Грішнової, М. Долішнього, Е. Лібанової, В. Супруна та інших українських вчених. Проблематику людського капіталу досліджували А. Гальчинський, О. Грішнова, О. Захарова, Е. Лібанова, О. Мартякова, О. Мудра, А. Переверзєва, а також у вищій школі-Т. Борова, О. Грішнова, Н. Верхоглядова, Т. Харчук. Щодо поняття соціального капіталу, то значний внесок в його обгрунтування цього поняття зробили українські дослідники Е. Гугнін, А. Колодій, М. Лесечко, Ю. Привалов, Ю. Саєнко, В. Степаненко, О. Убейволк, В. Чепак та Н. Черниш. Найбільш відомими зарубіжними авторами, які досліджували проблематику соціального капіталу, є П. Бурдьє, Дж. Коулмен, Р. Патнем, П. Сорокін, Ф. Фукуяма та інші.

Аналіз останніх досліджень та публікацій свідчить про недостатнє вивчення поняття професійного капіталу, його проблематики та ролі в галузі вищої освіти в Україні.

Метою статті $\epsilon$ запропонувати авторське трактування поняття “професійний капітал” у вищій школі та виокремити концептуальні умови формування професійного капіталу і його складових як одного 3 найбільш визначальних критеріїв поліпшення якості вищої освіти та проведення паралелей між відповідними педагогічними, економічними, політологосоціологічними категоріями в українських $\mathrm{i}$ американських дослідженнях.

Виклад основного матеріалу. Загалом, застосування поняття “капітал” у галузі освіти $€$ досить нетрадиційним, передовсім через походження цього терміна та його широке застосування в економічному контексті. Однак проаналізувавши сучасні педагогічні дослідження США, бачимо, що існує два кардинально різні підходи до використання поняття “капітал" в освіті: “бізнескапітал” та “професійний капітал”. Трактування поняття “бізнескапітал” та його ролі в удосконаленні освіти США нерозривно пов'язане з отриманням прибутку від освітньої діяльності часто шляхом оптимізації витрат на освіту. На противагу цьому, існує категорія “професійний капітал”, яка набула значного поширення у колах американських дослідників, у галузі освіти. Така популярність цього поняття стала реакцією на працю, присвячену поняттю “професійний капітал” впливових американських реформаторів освіти Енді Гаргрівза та Майкла Фуллана (Andy Hargreaves, Michael Fullan). Як справедливо стверджують автори, єдиним способом покращення освіти є поліпшення професії педагога шляхом збагачення та розвитку професійного капіталу (англ. professional capital) $[1,1]$. Згідно з Гаргрівзом, професійний капітал включає людський капітал (англ. human capital), соціальний капітал (англ. social capital) та рішеннєвий капітал (англ. decisional capital) [1,3].

Поняття “професійний капітал” розвинулося на грунті соціально-економічної категорії “людський капітал”, ключовою економічною складовою якої є слово “капітал”. Згідно з визначенням, “капітал (англ. capital) - це термін, який використовується у бізнесі для визначення сукупних ресурсів. У більш загальному розумінні - це вартість активів юридичної або фізичної особи (власність, паї та акції, банківський баланс, поточний прибуток 3 капіталу, що перебуває в обігу, - рента, дивіденди, процент тощо), або чиста вартість активів за мінусом суми зобов'язань” [6, 122-123]. Очевидно, це визначення стосується винятково матеріальних цінностей та відображає класичний економічний підхід до трактування цього терміна, адже за Марксом “капітал - це вартість, яка приносить додаткову вартість ... цінність, яка приносить потік доходу” [7, 239]. Інше визначення пропонує О. Іванілов: “капітал - сукупність матеріальних та грошових коштів, а також інтелектуальних здобутків, що використовуються у процесі виробництва та в інших сферах діяльності з метою отримання прибутку" $[5,320]$. Таке визначення не обмежує значення капіталу лише матеріальними здобутками, однак охоплює лише інтелектуальний аспект людського капіталу.

Зважаючи на факт, що якісна вища освіта $є$ тим нематеріальним благом забезпечення якого становить пріоритетне завдання вищої школи, можна стверджувати, що накопичення та розвиток капіталу $є$ не менш важливим для успішного функціонування закладів вищої освіти, ніж для роботи підприємства. Таким чином, вважаємо необхідним забезпечити розвиток й адміністрування університетів за зразком менеджменту підприємств та розглядати поняття професійного капіталу у широкому соціальноекономічному контексті.

На сучасному етапі поняття “людський капітал" викликає значне зацікавлення українських дослідників у галузі економічної теорії. Зокрема, Т. Харчук пропонує визначення людського капіталу як соціально-економічної 
категорії, що є сукупністю творчих здібностей, знань, умінь, особистих якостей і психологічних властивостей людини як його власність і накопичується за рахунок інвестицій та може використовуватися для отримання прибутку. При цьому людський капітал, на думку дослідниці, $€$ джерелом доходів не лише у вигляді грошових надходжень, а й нематеріальних благ, таких як моральне задоволення, підвищення соціального престижу, психологічна рівновага, можливість інтелектуального розвитку [8, 14]. О. Грішнова визначачає людський капітал як сформований або розвинений у результаті інвестицій і накопичений людьми (людиною) певний запас здоров'я, знань, навичок, здібностей, мотивацій, який цілеспрямовано використовується в тій чи тій сфері суспільного виробництва, сприяє зростанню продуктивності праці й завдяки цьому впливає на зростання доходів (заробітків) його власника $[3,13]$. Підсумовуючи, можемо стверджувати, що людський капітал розглядається як сукупність вроджених та набутих характеристик особи чи осіб, яка використовується $з$ метою отримання певних матеріальних чи нематеріальних благ.

Спираючись на трирівневий поділ людського капіталу, запропонований О. Грішновою $[4,10]$, вважаємо, що у галузі вищої освіти людський капітал також можна розглядати на трьох рівнях:

- на особистісному рівні людським капіталом називаються знання та навички, які викладач чи працівник закладу освіти здобув/ла шляхом освіти, професійної підготовки, практичного досвіду (використовуючи при цьому природні здібності) і завдяки яким він/вона може здійснювати ефективну професійну діяльність. Щодо людського капіталу студента, то він обов'язково охоплює природні здібності студента, його мотивацію до навчання та набуті знання. Очевидно, що на особистісному рівні поняття людського капіталу охоплює як набуті в процесі навчання та професійної діяльності характеристики особи, так і вроджені риси характеру та закладені природою здібності. Зважаючи на це, пропонуємо розмежувати складові особистісного людського капіталу як природний людський капітал $і$ набутий людський капітал.

- на мікроекономічному рівні або на рівні закладу освіти людський капітал $є$ сукупною кваліфікацією та професійними здібностями всіх працівників закладу освіти (адміністрації і професорсько-викладацького складу) та студентів, які відображаються у здобутках закладу вищої освіти в процесі ефективної організації праці. У цьому сенсі, на нашу думку, людський капітал відображається у престижності та рейтингу закладу вищої освіти, які, зі свого боку, в умовах ринкової економіки визначають його напрямки розвитку та економічну ефективність.

- на макроекономічному рівні або на національному та світовому рівні людський капітал включає накопичену національну та світову науково-методичну і дослідницьку спадщину, моделі й методи педагогічної та навчальної діяльності, сформований під впливом соціально-економічних, технологічних та організаційно-наукових чинників портрет викладача і студента вищої школи, сукупний досвід професійної підготовки та розвитку педагогів і студентів, стан та роль закладу вищої освіти у працевлаштуванні та, загалом, у самореалізації викладачів і студентів, а також результати впливу на вищу освіту, який здійснюється іншими стейкголдерами вищої школи.

Отож, як складова професійного капіталу у сфері вищої освіти людський капітал охоплює широке поле освітньої діяльності, що включає особистісні характеристики працівників закладів вищої освіти, викладачів, студентів та інших стейкголдерів окремих освітніх програм і вищої школи загалом, особливості діяльності окремого закладу вищої освіти, а також стан освітніх процесів на національному та світовому рівнях.

Людський капітал також розглядається як один iз компонентів інтелектуального капіталу [9, 109]. Хоча поняття “інтелектуальний капітал” було введено ще у 1946 році П. Друкером у роботі “Концепція корпорації”, сьогодні у науковій економічній літературі не сформульовано чіткого визначення цього поняття, натомість, виділяють декілька підходів до його тлумачення. Зокрема, Ж. Шульга, посилаючись на В. Іноземцева, який дотримується термінологічного підходу до визначення інтелектуального капіталу, розглядає його як своєрідний “колективний мозок”, який акумулює наукові та звичайні знання працівників, набутий досвід, інтелектуальну власність, спілкування й організаційну структуру, імідж організації, ii інформаційні мережі [9]. Інтелектуальний капітал охоплює категорію людського капіталу та збагачує їі певним організаційно-структурним елементом структурним капіталом, який, зі свого боку, включає технічне і програмне забезпечення, організаційну структуру, патенти і загалом усе те, що дозволяє персоналу реалізовувати свій потенціал [2, 88-89]. Таке визначення інтелектуального капіталу можна застосувати не лише до підприємств, а й до закладів вищої 
освіти. Зважаючи на важливість організаційної діяльності адміністрації та професорськовикладацького складу закладів вищої освіти, можна стверджувати, що поняття професійного капіталу вищої школи доцільно доповнити складовою інтелектуального капіталу.

На думку Гаргрівза і Фуллана, на додачу до людського капіталу, іншими невід'ємними складовими професійного капіталу є соціальний капітал та рішеннєвий капітал. Поняття “соціальний капітал” стосується взаємовідносин та взаємодії викладача 3 адміністрацією університету, колегами та студентами $[1,6]$. Соціальний капітал належить до ресурсів, що $\epsilon$ доступними через особисті та ділові мережі. До них належать: інформація, ідеї, ділові можливості, фінансовий капітал, влада, вплив, емоційна підтримка, репутація, довіра і співробітництво [4, 11]. Важливо наголосити, що соціальний капітал також охоплює соціально-економічні взаємовідносини між усіма стейкголдерами у вищій школі. Таким чином, очевидно, що соціальний капітал належить до ресурсів, що значною мірою формуються під впливом соціально-економічного і науковотехнічного розвитку, з одного боку, та психологоемоційних зв'язків з іншого.

На нашу думку, соціальний капітал передусім грунтується на категорії “співпраці/ співробітництва", яка є базовою передумовою набуття необхідних компетентностей викладачів, адміністративних працівників закладів освіти, студентів та інших зацікавлених сторін. Саме діяльність побудована на діалозі та взаємоповазі, спільних інтересах, пріоритетах та цінностях, $\epsilon$ найбільш продуктивною, оскільки забезпечує високий рівень мотивації усіх сторін таких взаємовідносин.

Зважаючи на невпинний розвиток технологій, поняття співпраці в сучасних умовах не може обмежуватися лише традиційним спілкуванням у спільному часі та просторі. Таким чином, вважаємо, що проблема ефективної співпраці постає особливо гостро за сучасних соціальноекономічних умов, коли є очевидною необхідність постійного спілкування онлайн. Особливо це стосується академічного середовища, в якому консультування та взаємообмін інформацією 3 колегами і професійними організаціями у всьому світі $€$ чи не найголовнішим аспектом професійної комунікації. Не менш важливим є ефективне спілкування та співпраця зі студентами, яка також все більше і більше набуває цифрового характеру.

У вищій школі академічну співпрацю можна схематично розділити на такі основні напрями:

1) співпраця з колегами:
1.1. Консультування;

1.2. Менторство;

1.3. Виступи на семінарах та конференціях;

1.4. Обмін досвідом (у формальному та неформальному середовищі) та ін.

2) співпраця з керівництвом та адміністрацією закладу вищої освіти:

2.1. Звітування;

2.2. Обмін досвідом;

2.3. Консультування та ін.

3) Співпраця зі студентами:

3.1. Аудиторна співпраця:

3.1.1. Практичні та семінарські заняття;

3.1.2. Лекції;

3.1.3. Онлайн курси;

3.1.3. Тьюторство;

3.1.4. Консультування та ін.

3.2. Позааудиторна співпраця:

3.2.1. Менторство;

3.2.2. Мотиваційна та організаційна діяльність та ін.

Отож, соціальний капітал відіграє провідну роль у забезпеченні ефективної педагогічної діяльності у вищій школі та вимагає постійного вдосконалення та самоорганізації.

Якщо людський та соціальний капітал мають тісний зв'язок 3 успішністю студентів, "рішеннсвий капітал" - це поняття, яке стосується розвитку навичок оцінювання та прийняття рішень. Для педагога важливо навчитися приймати рішення у неоднозначних ситуаціях. У цьому контексті професію викладача можна порівняти $з$ професією судді. Як суддя приймає рішення у різних справах з року в рік, самостійно, у співпраці з іншими людьми, у судовій залі та поза нею $[1,6]$. Таким чином, дослідники вважають, що рішеннєвий капітал викладача, аналогічно, формується з досвідом у процесі професійної діяльності. Не применшуючи жодною мірою значення досвіду у процесі формування професійної компетентності викладача, вважаємо доцільним розширити категорію рішеннєвого капіталу психологічним і морально-етичним аспектом 3 огляду принаймні на той факт, що професія викладача не обмежується лише функцією поширення знань, виконання педагогічного навантаження, проведення наукового дослідження. Більше того, цільова аудиторія, на яку спрямована педагогічна діяльність викладача, - студенти - не очікують від нього рішення винен чи не винен, як це відбувається у суді; очікування студентів радше стосуються, з одного боку, сфери нових відкриттів, пізнання незнаного, обдумування необміркованого, розширення наукових та життєвих горизонтів, а $з$ 


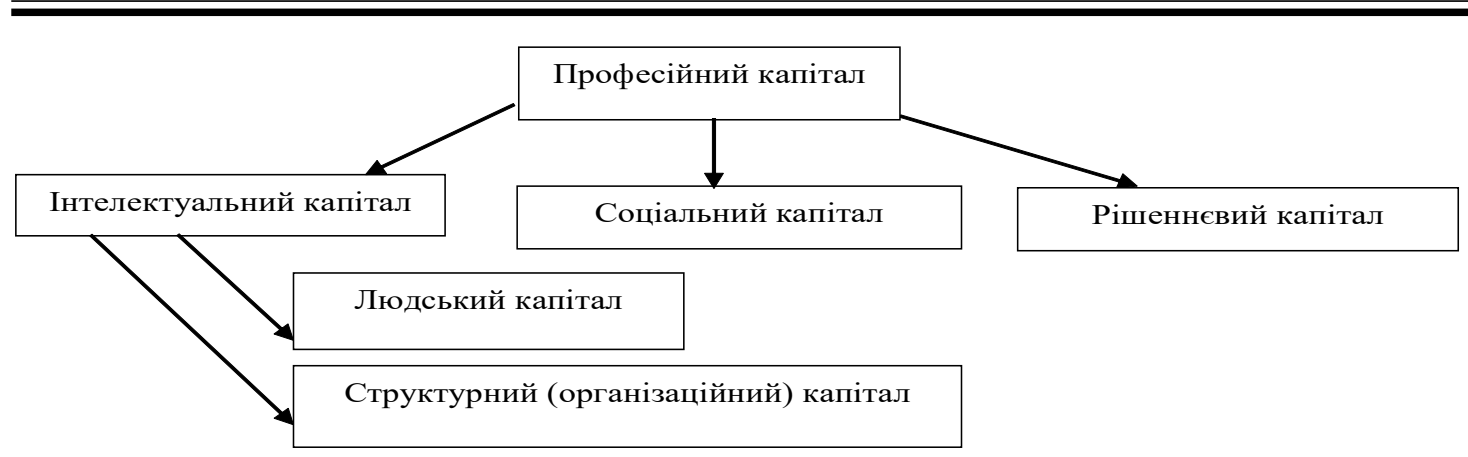

Рис. 1. Структура професійного капіталу у вищій школі

іншого - об'єктивного й неупередженого ставлення. Отож, вважаємо, що рішеннєвий капітал викладача повинен грунтуватися як на досвіді, так і на його психолого-емоційних характеристиках, морально-етичних цінностях і навичках.

Таким чином, грунтуючись на структурному підході до трактування поняття професійного капіталу у галузі вищої освіти, можна стверджувати, що його складовими є інтелектуальний капітал, рішеннєвий капітал та соціальний капітал (див. рис. 1).

Спираючись на функціональний підхід, можна сформулювати визначення професійного капіталу як педагогічної категорії: професійний капітал у вищій школі - це здатність забезпечувати високу якість вищої освіти, соціальні, інтелектуальні та рішеннєві ресурси вищої школи чи закладу вищої освіти репрезентовані особистісними характеристиками, знаннями тадосвідомпрофесорсько-викладацького складу, студентів, адміністрації та інших стейкголдерів вищої освіти, їх взаємовідносинами, досягненнями і здатністю приймати рішення та природою таких рішень.

Висновки. Запропоноване трактування категорії “професійний капітал” у вищій школі охоплює ті нематеріальні цінності закладів вищої освіти, які гарантують забезпечення високої якості вищої освіти та генерують структуроване бачення напрямів розвитку і збагачення цих нематеріальних ресурсів. Отож, можемо вважати, що професійний капітал є однією 3 основних передумов забезпечення якісної вищої освіти. Аналіз цього поняття та його складових, дає змогу переосмислити й систематизувати ті напрями та аспекти науково-педагогічної діяльності викладача вищої школи, які потребують постійного вдосконалення. Тільки той викладач, який може змінюватися, розвиватися й адаптуватися до нових моделей навчання, економічних умов та новітніх технологій шляхом збагачення і вдосконалення професійного капіталу, $\epsilon$ найбільшою цінністю університету, гарантом забезпечення якісної вищої освіти. Оскільки професійний капітал також охоплює усю мережу взаємовідносин між усіма стейкголдерами освітніх програм закладів вищої освіти та вищої школи загалом, вивчення розвитку й ефективності таких взаємовідносин сприятиме зростанню рівня професійної підготовки студентів закладів вищої освіти в Україні, зміцнить співпрацю між стейкголдерами, які беруть участь в освітньому процесі, а також окреслить напрями розвитку таких взаємовідносин з метою забезпечення високої якості вищої освіти в Україні.

\section{ЛІТЕРАТУРА}

1. Hargreaves, A., Fullan, M. Professional Capital: Transforming Teaching in Every School. Teachers College, Columbia University. 2012. 222 p.

2. Бех Ю.В. Інтелектуальний капітал організації: структурно-функціональний підхід. Політологічний вісник. 2014. В. 74. С. $86-97$.

3. Грішнова О.А. Людський капітал: формування в системі освіти і професійної підготовки. Київ, 2001. 254 с.

4. Грішнова О.А. Нагромадження людського, інтелектуального і соціального капіталу підприємства як основна форма його капіталізації. Вісник Донецького університету економіки і права. 2011. № 1. С. 10-13.

5. Іванілов О.С. Економіка підприємства. Київ, 2009. 728 c. URL: https://shron1.chtyvo.org.ua/ Ivanilov_Oleksandr/Ekonomika_pidpryemstva.pdf

6. Завадський Й.С., Осовська Т.В., Юшкевич О.О. Економічний словник. Київ, 2006. С. 355. URL: http:// library.nlu.edu.ua/POLN_TEXT/KNIGI/KONDOR/ EKONOMIC_SL_2006.pdf

7. Словарь современной экономической теории. Науч. ред. А. Г. Пивоваров. Москва, 1997. 608 с.

8. Харчук Т.В. Управління розвитком людського капіталу в організаціях системи вищої освіти: дис. ... канд. економ. наук: 08.06.01. Київ, 2005. 184 с.

9. Шульга Ж.О. Інтелектуальний капітал як об’єктивна економічна категорія. Вісник Бердянського університету менеджменту і бізнесу. 2010. № 2(10). С. 106-111.

\section{REFERENCES}

1. Hargreaves, A., Fullan, M. (2012). Professional Capital: Transforming Teaching in Every School. Teachers College, Columbia University, 222 p. [in English]. 


\section{ВИКОРИСТАННЯ ТВОРІВ СУЧАСНИХ УКРАЇНСЬКИХ КОМПОЗИТОРІВ ДЛЯ ДІТЕЙ І ЮНАЦТВА У ФОРТЕПІАННІЙ ПІДГОТОВЦ МАЙБУТНІХ МУЗИКАНТІВ-ПЕДАГОГІВ}

2. Hrishnova, O.A. (2001). Liudskyi kapital: formuvannia $\mathrm{v}$ systemi osvity i profesiynoi pidhotovky [Human capital: formation in the system of education and professional training]. Kyiv, 254 p. [in Ukrainian].

3. Bekh, Yu.V. (2014). Intelektualnyi kapital orhanizatsiyi: strukturno-funktsionalnyi pidkhid [Intellectual capital of an organization: structural and functional approach]. Politology Bulletin. 2014. Vol. 74. pp. 86 -97. [in Ukrainian].

4. Hrishnova, O.A. (2011). Nahromadzhennia liudskoho, intelektualnoho i sotsialnoho kapitalu pidpryemstva yak osnovna forma yoho kapitalizatsii [Accumulation of human, intellectual and social capital of the enterprise as the main form of its capitalization]. Bulletin of the Donetsk University of Economy and Law. No. 1. pp. 10-13. [in Ukrainian].

5. Ivanilov, O.S. (2009). Ekonomika pidpryemstva [Economy of an Enterprise]. Kyiv, 728 p. [in Ukrainian].
6. Zavadskyi, Y.S., Osovska, T.V.\& Yushkevych, O.O. Ekonomichnyi slovnyk [Economic Dictionary]. Kyiv. 2006. p. 355. Available at: http://library.nlu.edu.ua/POLN TEXT/ KNIGI/KONDOR/EKONOMIC SL 2006.pdf [in Ukrainian].

7. Slovar sovremennoy ekonomicheskoy teorii (1997). [Dictionaty of contemporary economic theory]. (Ed.). A.H. Pivovarov. Moscov, 608 p. [in Russian].

8. Kharchuk, T.V. (2005). Upravlinnia rozvytkom liudskoho kapitalu v orhanizatsiakh systemy vyshchoi osvity [Managenemt of the development of human capital in institutions of higher education]. Candidate's thesis. Kyiv, 184 p. [in Ukrainian].

9. Shulha, Zh.O. (2010). Intelektualnyi kapital yak obyektyvna ekonomichna katehoria [The intellectual capital as an objective economic category]. Bulletin of Berdyansk University of Management and Business. No. 2(10).pp. 106-111.

Стаття надійшла до редакції 16.09.2020

УДК 378:37.011.3-051:780.616.432:781.5-053.5/6

DOI:

Ірина Новосядла, кандидат мистеитвознавства, дочент кафедри методики музичного виховання та диригування ДВНЗ “Прикарпатський національний університет імені Василя Стефаника"

\section{ВИКОРИСТАННЯ ТВОРІВ СУЧАСНИХ УКРАЇНСЬКИХ КОМПОЗИТОРІВ ДЛЯ ДІТЕЙ І ЮНАЦТВА У ФОРТЕПІАННІЙ ПІДГОТОВЦІ МАЙБУТНІХ МУЗИКАНТІВ-ПЕДАГОГІВ}

У статті актуалізовано питання оновлення репертуару студентів з предмету "Профільний інструмент фортепіано”. Розглянуто художні особливості композицій сучасних авторів, проаналізовано вибрані п'єси як приклади втілення образного змісту засобами модернової композиторської мови; охарактеризовано їх стильові риси. Зазначено, що вивчення творів різних жанрів і стилів сприяє розширенню світогляду студентів, збагаченню їх уявлень про сучасну украӥнську музику, ознайомленню з творчістю маловідомих композиторів, а також розвитку піаністичних навичок і творчого мислення.

Ключові слова: сучасна украӥнська фортепіанна музика для дітей і юнацтва; заклад вищої освіти; навчання гри на фортепіано; дидактичний репертуар; музично-педагогічна діяльність; розвиток творчого мислення.

Jim. 8.

Iryna Novosyadla, Ph.D.(Art Science), Associate Professor of the Music Education and Conducting Methods Department, Vasyl Stefanyk Precarpathian National University

\section{ON USING CONTEMPORARY UKRAINIAN COMPOSERS' WORKS FOR CHILDREN AND YOUTH IN PIANO TRAINING OF FUTURE MUSICIANS AND EDUCATORS}

The article defines the contemporary priorities of choosing the teaching material for training the musician and educator. On the one hand, the material must meet the key requirements of the national education and upbringing, and, on the other hand, it must bring the requirements of the globalized community into conformity with its cultural artistic integration processes. The article deals with the issue of enriching the repertoire of the students of speciality 014. Secondary Education (Musical Art) on the subject "Piano as the Major Instrument" with the works for children and youth created by contemporary Ukrainian composers. During the last decades, a number of multi-genre interesting compositions for the piano have been included into Ukrainian teaching literature. They have been created by such professional composers, teachers-pianists and concert Jazz performers as S. Sukhoshcheyeva, Ia. Bobalik, L. Pratsyuk, E. Brylin, K. Maydenberg-Todorova, N. Lahodyuk, O. Saratskiy and others. Taking into consideration the tastes of the contemporary younger generation, authors actively turn to various types of jazz music, use modern music related vocabulary, resort to tone painting and special timber effects. The present research 